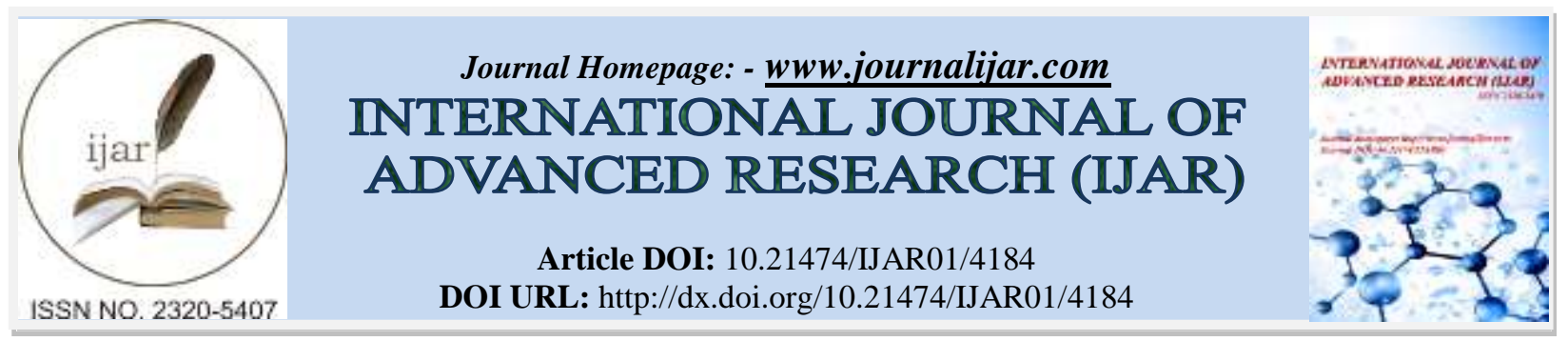

RESEARCH ARTICLE

\title{
MORPHO-PHYSIOCHEMICAL AND GENETIC CHARACTERIZATION OF RICE VARIETIES (ORYZA SATIVA L.) IN DIFFERENT GEOGRAPHICAL AREAS OF NORTHERN INDIA.
}

\author{
Sonu Kumar Chaudhary ${ }^{1}$, Diksha $\operatorname{Varma}^{2}$, Dr. Krishan Pal ${ }^{1 *}$ and Dr. Manisha Tiwari ${ }^{2} *$ \\ 1. Department of Agriculture, Shri Venkateshwara University, Gajraula, Uttar Pradesh 244236, India. \\ 2. Bio-Organic Chemistry Laboratory, Dr. B. R. Ambedkar Centre for Biomedical Research, University of Delhi, \\ Delhi 110007, India.
}

\section{Manuscript Info}

Manuscript History

Received: 13 March 2017

Final Accepted: 14 April 2017

Published: May 2017

Key words:-

Oryza sativa L., morpho-physiochemical

characters, Basmati, Rice.

\section{Abstract}

In the present study, prominently evolved varieties of Indica rice (Oryza sativa L.) were studied and characterized. Effect of temperature and humidity on the grain yield and grain quality in different geographical areas of Northern India was studied. This would ensure the selection of rice varieties with respect to different geographical climatic regions. Seven varieties of rice were studied and characterized by the effect on their morpho-physiochemical characters in different climatic conditions of Uttar Pradesh and Haryana, India. All the seven varieties of rice except Sambha Sub-1 showed presence of $f g r$ gene whose protein product are responsible for the peculiar fragrance of Basmati rice. This was also confirmed by the chemical assay for aroma. Morho-physiological characters of the crop namely; plant height, plant biomass, root biomass, leaf area, panicle length, spikelets per panicle, grain yield per plant and days of maturity were found to significantly correlate with each other with $(P>0.5)$. Biochemical studies performed showed the effect of temperature in different climatic conditions on total chlorophyll, chlorophyll a and chlorophyll $\mathrm{b}$, total sugar and total protein. A significant correlation ( $\mathrm{p}$ $>0.05$ ) was observed between the higher and lower temperature and humidity respectively and different morpho-physiochemical characters. Four varieties of Basmati namely VB-21, VB-24, PB1509, PB-1121 has been found to show higher morphophysiochemical characters and grain yield per plant. VB-21 and VB24 has been observed to resist the high temperature and low humidity in the region of Haryana as they have shown to produce higher grain yield, seed weight and grain quality.

Copy Right, IJAR, 2016. All rights reserved.

\section{Introduction:-}

Rice is one of the most important field crops of the world providing staple food to millions. It is grown in 114 countries across the world and the population of 150 million has continuing cultivation in near $11 \%$ of the world's cultivated land. More than $90 \%$ of the world rice is produced and consumed in Asia as it is an indispensable source of calories for almost half of the world population within the continent. Rice belongs to the genus Oryza and has two cultivated and 22 wild species. The two cultivated species are Oryza.sativa $L$ and Oryza.glaberrima. Oryza.sativa $L$

Corresponding Authors: - Dr. Krishan Pal.

Address: - Department of Agriculture, Shri Venkateshwara University, Gajraula, Uttar Pradesh 244236, India. 
is grown all over the world and is known for its peculiar fragrance present in the distinct varieties of Basmati [12]. It has two major varieties var. Indica and var. Japonica. Being able to grow in this wide spectrum of climates is the reason that rice is one of the most widely eaten foods of the world. The continuing specter of climate changes is casting a long shadow on agriculture across the world but particularly in India [1]. Environmental changes are likely to increase the pressure on Indian Agriculture, in addition to the on-going stresses of yield stagnation, land-use, competition for land, water another resources and globalization, it is estimated that by 2012 food grain requirement would be almost 30-50\% more than the current demand. This will have to be produced from the same or even the shrinking land resources due to increasing competition [14]. Agriculture might face an unprecedented climate challenge in the next century. However, this change may have a positive impact on rice production in some areas; for example, a global temperature rise might allow more rice production to occur in the northern region of some countries such as China and India, or growing two rice crops where, until now, only one can be grown per year. Rice grain size is a main component which determines rice quality and which also has a direct effect on the marketability or commercial success of improved cultivars [16]. Therefore, it is important to understand the distribution, variability for different morphological and grain characteristics, adaptability to harsh environments and specialty uses of native germplasm [1].

Knowledge of genetic diversity in addition of rice crop species is fundamental to its improvement. A variety of molecular and morphological descriptors are used to characterize genetic diversity among and within rice varieties. Substantial variations exist among the rice genotypes for various morphological, physiological and agronomic traits, but they are sensitive to the environment and have limited coverage in the genome, hindering their usage in breeding programme. Improved production and access to this vital food crop is required which feeds more than half the world's population while providing income for millions of rice producers, processors and traders.

In this study an attempt has been made to study the effect of temperature and humidity on the morphological, physiochemical, genetic characters, grain yield and grain quality of seven rice varieties namely; Vallabh Basmati21, Vallabh Basmati-22, Vallabh Basmati-23, Vallabh Basmati-24, Pusa Basmati 1509, Pusa Basmati 1121, Sambha Sub-1 in different geographical areas of Northern India. This will ensure the selection of rice varieties with respect to different geographical climatic regions and will further help to improve their yield and grain quality to fulfill the substantial food requirement of India and the other counties of the world.

\section{Materials and Methods:-}

\section{Collection and sowing of the paddy Crop:-}

In the present study seven varieties of paddy Oryza sativa L were collected from National Seeds Corporation, New Delhi, Indian Agriculture Research Institute, New Delhi and Basmati Import and Export Foundation, Meerut. Seven varieties of paddy were selected for the study namely, Vallabh Basmati-21 (VB-21), Vallabh Basmati-22 (VB-22), Vallabh Basmati-23 (VB-23), Vallabh Basmati-24 (VB-24), Pusa Basmati 1509 (PB-1509), Pusa Basmati 1121 (PB1121) and Sambha Sub-1 (SS-1). The seeds were collected and sown on the agricultural field of Hastinapur, Uttar Pradesh and Asaudha, Haryana, India as given in Table 1. The experiment was laid out in Randomized Block Design (RBD) with three replications for each genotype with size of each plot $-8 \mathrm{~m} \times 1 \mathrm{~m}$, plot distance $45 \mathrm{~cm}^{2}$ and row distance $20 \mathrm{~cm}^{2}$ in sandy loamy soil in kharif season in 2016 . Healthy seeds were selected by putting them in water and stirring well and then the floated seeds were rejected. The germinated seeds were then sown in raised seedbed. The seedlings were transplanted on the main field after 28 days. Only one seedling was transplanted per hill. N: P: K -20: 10: $10 \mathrm{Kg} / \mathrm{Ha}$ (in two split doses) of the fertilizer was used in the field during maturation stage while Chloroform 3g @ $\mathrm{Kg} / \mathrm{Ha}$ was used against Hispa. The temperature and amount of humidity in the environment during various stages of rice development are listed in the Table 1.

Table 1:- Climatic temperature, humidity and wind in the two regions of northern India observed during paddy cultivation in the kharif season 2016.

\begin{tabular}{|l|r|r|r|r|r|r|r|r|}
\hline Region & \multicolumn{3}{|c|}{ Hastinapur (Uttar Pradesh) } & \multicolumn{3}{c|}{ Asaudha (Haryana) } \\
\hline Weather & \multicolumn{1}{|c|}{$\begin{array}{c}\text { Temperature } \\
\left({ }^{\circ} \mathbf{C}\right)\end{array}$} & $\begin{array}{c}\text { Humidity } \\
(\%)\end{array}$ & $\begin{array}{c}\text { Wind } \\
(\mathbf{\% p h})\end{array}$ & \multicolumn{2}{c|}{$\begin{array}{c}\text { Temperature } \\
\left({ }^{\circ} \mathbf{C}\right)\end{array}$} & $\begin{array}{c}\text { Humidity } \\
(\%)\end{array}$ & $\begin{array}{c}\text { Wind } \\
(\mathbf{k p h})\end{array}$ \\
\hline Stages & \multicolumn{1}{|c|}{ Max. } & \multicolumn{1}{c}{ Min. } & & & \multicolumn{1}{c|}{ Max. } & \multicolumn{1}{c|}{ Min. } & \\
\hline Vegetative & 35 & 28 & 76.7 & 10 & 35.4 & 28.6 & 77.4 & 12.1 \\
\hline Flowering & 31.36 & 26.27 & 73.64 & 8.27 & 31.45 & 26.55 & 70.82 & 11.00 \\
\hline Milking & 31.75 & 24.50 & 63.38 & 8.88 & 34.63 & 25.75 & 47.25 & 11.38 \\
\hline Maturity & 32.38 & 21.13 & 46.13 & 10.63 & 33.75 & 23.00 & 37.63 & 22.38 \\
\hline
\end{tabular}


Max. - Maximum, Min. - minimum

Morphological and Physiochemical Study:-

Five plants were randomly selected for the morpho-physiochemical study from the middle rows leaving the border rows in each plot. The data were recorded on individual plants basis from five randomly selected plants and the mean value was calculated for further analysis. Morphological characters such as plant height $(\mathrm{cm})$, number of tillers, number of leaves, Flag leaf length $(\mathrm{cm})$, Flag leaf breadth $(\mathrm{cm})$, Leaf area $\left(\mathrm{cm}^{2}\right)$, root length $(\mathrm{cm})$, dry and fresh root biomass $(\mathrm{g})$, dry and fresh plant biomass $(\mathrm{g})$, panicle length $(\mathrm{cm})$, spikelets per panicle, Grain yield per Hill, Grain yield per plant, days taken by plants to mature and 1000 seeds weight were studied and recorded. The plant height was measured from the base of the shoot above the soil up to the edge of the leaf. Panicle length was measured from the upper topmost node up to the tip of the panicle. Grain yield was measured after harvesting the seeds when the moisture content of the seeds was approximately 14\%. Leaf area was measured by length- width measurement method given by Yoshida et al (1981) [20]. It uses a correction factor (k). Leaf area was measured by the following equation:

Leaf Area $\left(\mathrm{cm}^{2}\right)=\mathrm{k} x$ length $(\mathrm{cm}) \mathrm{x}$ breadth $(\mathrm{cm})$

The correction factor $(\mathrm{k})$ used for the rice leaves ranges from 0.67 to 0.80 , depending on the variety and the growth stage. The value of 0.75 , however, can be used for the all growth stage except the seedling and maturity stage.

\section{Fragrance Genotyping study of Rice Varieties:-}

\section{DNA Extraction:-}

DNA extraction was performed by protocol modified from Keb-Llanes et al. (2002) [7]. Leaf tissue from each sample of the rice variety was collected in the vegetative stage from the fields and stored in $-80^{\circ} \mathrm{C}$ freezer. The frozen leaf tissue was cut into pieces and grinded in liquid nitrogen. The grounded fine powder was then dissolved in $500 \mu \mathrm{l}$ DNA extraction buffer $\left(0.038 \mathrm{~g}\right.$ sodium bisulphite added to pre-warmed buffer at $\left.60^{\circ} \mathrm{C}\right)$ and thoroughly vortexed. The solution was incubated at $65^{\circ} \mathrm{C}$ for 40 minutes and then kept at room temperature for 5 minutes. 200 $\mu 1$ of $5 \mathrm{M}$ chilled potassium acetate was added to the sample solution, vortexed and kept at $20^{\circ} \mathrm{C}$ for 20 minutes. Solution was then centrifuged at $1000 \mathrm{xg}$ for 15 minutes at $4^{\circ} \mathrm{C}$ and to $100 \mu 1$ of the supernatant $100 \mu 1$ of chilled isopropanol added. After keeping the supernatant at room temperature for 10 minutes, it was centrifuged at $1000 \times \mathrm{xg}$ for 5 minutes at $4{ }^{\circ} \mathrm{C}$. The pellet obtained was then washed thrice with absolute and $70 \%$ alcohol respectively at $100 \mathrm{xg}$ for 10 minutes at $4^{\circ} \mathrm{C}$. The final pellet of DNA obtained was dried in the lyophilizer and dissolved in DEPC water and stored at $20^{\circ} \mathrm{C}$. The DNA samples were quantified by A 260/280 method.

\section{Selection of Markers:-}

The $f g r$ gene responsible for the rice fragrance was studied and four markers that have been shown to be present in most of the fragrant variety of rice were selected. $[2,6,10,15]$. The primer sequence of the gene markers is given in Table 2. Primers ESP + IFAP + INSP + EAP were used for performing Nested PCR for gene specific amplification.

Table 2:- Aroma gene markers, their respective melting temperature and PCR product gene length.

\begin{tabular}{|c|l|c|c|l|}
\hline Sr no. & \multicolumn{1}{|c|}{ Marker } & Tm $\left({ }^{\circ} \mathbf{C}\right)$ & Gene length bases (bp) & \multicolumn{1}{|c|}{ Reference } \\
\hline 1 & RM 515 & 58 & $200-230$ & Kibria et al (2008) \\
\hline 2 & RM 342 & 55 & $132-150$ & Kibria et al (2008) \\
\hline 3 & ESP + IFAP + INSP + EAP & 58 & $355-580$ & Bradbury et al (2005) \\
\hline 4 & L06 & 60 & $325-376$ & Chen et al (2008) \\
\hline
\end{tabular}

\section{Fragrance Genotyping by PCR:-}

PCR reaction was carried out on a VERITI thermal cycler. The reaction volume was adjusted to $20 \mathrm{ml}$, containing 100ng of template DNA, $10 \mathrm{mM}$ dNTPs, 1 unit of Taq DNA polymerase, $1 \mathrm{X}$ Taq buffer, $25 \mathrm{mM} \mathrm{MgCl}_{2}, 10 \mathrm{mM}$ of forward and reverse primers. Cycling conditions were set to 4 minutes at $95^{\circ} \mathrm{C}$, followed by 32 cycles of $95^{\circ} \mathrm{C}$ for 30 seconds, $55^{\circ} \mathrm{C}-60^{\circ} \mathrm{C}$ for 30 seconds, and $72^{\circ} \mathrm{C}$ for 1.3 minutes, and with a final extension at $72^{\circ} \mathrm{C}$ for 10 minutes. The final PCR products were subjected to electrophoresis on a $1.2 \%$ agarose gel and observed on GEL DOC visualizing system $[2,10]$.

\section{Biochemical Study:-}

Isolation of Chloroplast and Estimation of Chlorophylls:-

$2 \mathrm{~g}$ of rice sample leaves harvested in the flowering stage and was washed thoroughly under the tap water, cut into small pieces and grinded in liquid nitrogen. To the powder $1 \mathrm{ml}$ of $1 \mathrm{xCIB}$ buffer $(0.33 \mathrm{M}$ Sorbitol, $0.1 \mathrm{M}$ Tris $\mathrm{HCl}$ 
PH-7.8, 5mM MgCl2, $10 \mathrm{mM} \mathrm{NaCl}, 2 \mathrm{mM}$ EDTA) with bovine serum albumin (BSA) and centrifuged at 200xg for 2 minutes. The supernatant was transferred leaving white pellet behind, into the chilled $50 \mathrm{ml}$ centrifuge tubes and centrifuged at $1000 \mathrm{xg}$ for 7 minutes. A green pellet obtained was secured. The green pellet was broken gently by finger tapping and resuspended in $2 \mathrm{ml}$ of $1 \mathrm{x}$ CIB buffer with BSA and mixed gently by pipetting up and down. The suspended pellet was then centrifuged at $300 \mathrm{xg}$ for 5 minutes and pooled into one centrifuge tube. The pellet was finally mixed with $500 \mu \mathrm{l}$ of $1 \mathrm{x}$ CIB buffer without BSA. Absorbance of the solution was read at $645,663 \& 652 \mathrm{~nm}$ against the solvent (80\% acetone) as blank. The amount of the chlorophyll present in the extract (mg chlorophyll/g tissue) was calculated using the following equation given by Sadasivam and Manickham et al (1996) [17]:

mg chlorophyll a/g tissue $=12.7($ A633 $)-2.69($ A645 $) \times \mathrm{V} / 1000 \times \mathrm{W}$

$\mathrm{mg}$ chlorophyll b/g tissue $=22.9(\mathrm{~A} 645)-4.68(\mathrm{~A} 663) \times \mathrm{V} / 1000 \times \mathrm{W}$ and

$\mathrm{mg}$ total chlorophyll $/ \mathrm{g}$ tissue $=20.2(\mathrm{~A} 645)-8.02(\mathrm{~A} 663) \times \mathrm{V} / 1000 \times \mathrm{W}$

where, A-absorbance at specific wavelengths

$\mathrm{V}$-final volume of chlorophyll extract in $80 \%$ acetone

$\mathrm{W}$-fresh weight of tissue extracted.

\section{Assay of rice Fragrance:-}

Twenty six freshly harvested milled rice grains from each of the rice varieties were crushed into fine powder and taken in the conical flask. About $10 \mathrm{ml} 1.7 \% \mathrm{KOH}$ solution was added to each of the conical flask and covered immediately with aluminum foil and left at room temperature for about 1 hour. The samples were scored on 1-4 scale with $1,2,3$ and 4 corresponding to absence of aroma, slight aroma, moderate aroma and strong aroma, respectively. The score for each sample was recorded by a panel of five experts who have experience in aromatic rice breeding and quality evaluation $[3,6,12]$.

\section{Estimation of total Soluble sugar:-}

The total soluble sugar present in the different varieties of rice seeds was measured by Anthrone method as described by Hedge and Hofreiter et al (1962) [5]. $100 \mathrm{mg}$ of the powdered grains was taken in a test tube and $80 \%$ of $10 \mathrm{ml}$ ethanol was added, vortexed and hydrolysed by keeping it in a boiling water bath for 30 minutes. After cooling to the room temperature the sample was centrifuged at $1000 \mathrm{xg}$ for 10 minutes and collected in a beaker. To the remaining residue $10 \mathrm{ml}$ of $80 \%$ ethanol was added and the method was repeated and the supernatant was pooled together. The total collected supernatant was evaporated in the vacuum evaporator and $50 \mathrm{ml}$ of water added and vortexed to solubilize the sugar to use it for total sugar estimation. For estimation $0,0.2,0.4,0.6,0.8$ and $1.0 \mathrm{ml}$ of the working standard $(1 \mathrm{mg} / \mathrm{ml})$ of D-glucose was used while water served as blank. After making the volume to $1 \mathrm{ml}$ in all the test tubes including the sample tubes with distilled water, $4 \mathrm{ml}$ of anthrone reagent $(200 \mathrm{mg}$ anthrone dissolved in $100 \mathrm{ml}$ ice cold $95 \% \mathrm{H} 2 \mathrm{SO} 4$ just before use) was added to all the tubes. The tubes were heated in a boiling water bath for 8 minutes. Rapidly the tubes were cooled in an ice bath and the change in color was read from green to dark green at 630 $\mathrm{nm}$ in a spectrophotometer. Standard curve was plotted by drawing the graph for the concentration of the standard on the $\mathrm{X}$-axis versus the absorbance on the $\mathrm{Y}$-axis. The amount of total sugar present in the sample tube was measured.

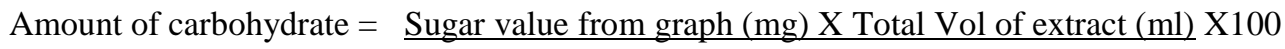

in sample $(\% \mathrm{mg}) \quad$ Aliquot sample used $(0.5 \mathrm{ml}) \mathrm{X}$ Wt. of sample $(\mathrm{mg})$

\section{Estimation of Total Protein:-}

To the finely powdered seed samples of $0.02 \mathrm{~g}, 400 \mu \mathrm{l}$ of the extraction buffer was added containing $0.5 \mathrm{M}$ Tris- $\mathrm{HCl}$ (pH 8.0), $0.2 \%$ SDS, $5 \mathrm{M}$ urea and $1 \%$ 2-mercaptoethanol. The mixture was than vortexed and centrifuged at $1000 x g$ for 5 minutes at room temperature. After centrifuging samples, the crude proteins were recovered as clear supernatant on the top of the tube. Then the supernatant was transferred into new $1.5 \mathrm{ml}$ eppendorf tubes and were stored at $-20^{\circ} \mathrm{C}$ [18]. Bradford's method for protein quantification, modified by Nicholas J. Kruger was used for estimation of total protein in the seeds of different rice varieties by Standard Assay Method [13]. The supernatant containing the protein was diluted to $(1,1: 10,1: 100,1: 1000)$ in duplicates. Protein BSA standard was prepared in volumes of $10,20,40,60,80$, and $100 \mu \mathrm{L}$ of $1 \mathrm{mg} / \mathrm{ml}$ and made each up to $100 \mu \mathrm{L}$ with distilled water for the preparation of the calibration curve. $100 \mu \mathrm{L}$ of distilled water was used as a blank. To these $5 \mathrm{~mL}$ of protein reagent was added and mixed well by inversion or gentle vortex mixing. Absorbance was measured at A595 between 2 min and 1 hour after mixing. The $100 \mu \mathrm{g}$ standards should give an A595 value of about 0.4. 


\section{Statistical Analysis:-}

The data of the morpho-physiochemical characters was statistically analyzed using Microsoft Excel 2010. To find the correlation dependence of morphological and biochemical parameters on temperature and humidity Student's t-test was applied. Correlation coefficient for each correlation between the morphological and biochemical parameters with each other was also found.

\section{Results and Discussion:-}

\section{Morphological and Physiological:-}

Different morphological characters of each rice variety from each region of Uttar Pradesh and Haryana were measured and standard deviation from the mean and standard error for each observation has been recorded as listed in Table 3 and 4. As observed from the data rice grown in the region of Uttar Pradesh with moderate temperature and humidity, had shown to have optimally good morpho-physiological characters as compared to the region of Haryana with higher temperature and lower humidity. Some varieties of rice had shown to have no direct effect of temperature and humidity on grain yield and quality. Although, the overall yield and quality of all the varieties of rice was higher in the region of Uttar Pradesh, VB-21, VB-24, PB-1509, PB-1121 and Sambha Sub-1 had shown to have higher plant height, number of tillers, plant biomass, root biomass, root length, leaf area, panicle length, spikelet's per panicle, seed weight, grain yield per hill and grain yield per plant in both the regions of Northern India. VB-21, VB-24, Sambha Sub-1 had been observed to produce the higher grain yield and seed weight than the other varieties grown in the region in higher temperature and lower humidity of Haryana.

Table 3:- Morphological parameters of paddy varieties of Hastinapur (Uttar Pradesh) State

\begin{tabular}{|c|c|c|c|c|c|c|c|c|}
\hline \multicolumn{9}{|c|}{ Hastinapur (Uttar Pradesh) State } \\
\hline \multirow{2}{*}{$\begin{array}{c}\text { S.N } \\
\text { o. }\end{array}$} & \multirow[t]{2}{*}{ Characters } & \multicolumn{7}{|c|}{$\begin{array}{ll}\text { Paddy varieties } \\
\end{array}$} \\
\hline & & VB-21 & VB-22 & VB-23 & VB-24 & PB-1509 & PB-1121 & SS-1 \\
\hline 1 & Plant Height $(\mathrm{cm})$ & $\begin{array}{l}112 \\
\pm 2.5 * *\end{array}$ & $\begin{array}{l}\text { 84.4 } \pm 2.0 \\
*\end{array}$ & $\begin{array}{l}\text { 85.4 } \pm 4.2 * \\
*\end{array}$ & $\begin{array}{l}\mathbf{1 0 5} \pm 2.9 \\
* *\end{array}$ & $\begin{array}{l}79.8 \pm 4.4^{*} \\
*\end{array}$ & $\begin{array}{l}\mathbf{1 0 3} \pm 3.5 \\
* *\end{array}$ & $\begin{array}{l}\mathbf{8 4 . 2} \pm 3.9 \\
* *\end{array}$ \\
\hline 2 & Tillers per Hill & $\begin{array}{l}\mathbf{1 5 . 0 5} \pm 1.2 \\
*\end{array}$ & $\begin{array}{l}\text { 18.33 } \pm 1 \\
5 * *\end{array}$ & $\begin{array}{l}\mathbf{1 3 . 5 2} \pm 3.5 \\
*\end{array}$ & $\begin{array}{l}\mathbf{1 6 . 3 7} \pm 1 \\
2 *\end{array}$ & $\begin{array}{l}\mathbf{1 5 . 2 4} \pm 0.9 \\
* *\end{array}$ & $\begin{array}{l}\mathbf{1 6 . 7 \pm 1 . 4} \\
5 *\end{array}$ & $13 \pm 2.5 *$ \\
\hline 3 & Flag leaf length $(\mathrm{cm})$ & $\mathbf{5 3} \pm 1.5^{*}$ & $\mathbf{5 0} \pm 2.0 *$ & $48 \pm 3.1^{*}$ & $\begin{array}{l}\mathbf{5 8} \pm 2.8^{*} \\
*\end{array}$ & $69 \pm 2.6^{*}$ & $\begin{array}{l}\mathbf{5 5} \pm 1.75 \\
*\end{array}$ & $\begin{array}{l}\mathbf{5 7} \pm 2.33 \\
* *\end{array}$ \\
\hline 4 & Flag leaf width (mm) & $\begin{array}{l}\mathbf{1 5 0} \pm 1.75 \\
*\end{array}$ & $\begin{array}{l}100 \pm 2.1 \\
2 *\end{array}$ & $180 \pm 2.6^{*}$ & $\begin{array}{l}\mathbf{1 2 0} \pm 2.4 \\
*\end{array}$ & $74 \pm 3.3^{*}$ & $\begin{array}{l}\mathbf{1 8 0} \pm 2.2 \\
* *\end{array}$ & $\begin{array}{l}\mathbf{1 5 0} \pm 1.9 \\
*\end{array}$ \\
\hline 5 & Leaf Area $\left(\mathrm{cm}^{2}\right)$ & $\begin{array}{l}\mathbf{5 4 . 8 3} \pm 3 * \\
*\end{array}$ & $37 \pm 0.4^{*}$ & $\begin{array}{l}\mathbf{3 7 . 8 0} \pm 4.2 \\
* *\end{array}$ & $\begin{array}{l}\mathbf{4 2 . 0 5} \pm 2 . \\
6 * *\end{array}$ & $\begin{array}{l}\mathbf{4 0 . 6 7} \pm 4.2 \\
* *\end{array}$ & $\begin{array}{l}\text { 41.16 } \pm 4 . \\
3 * *\end{array}$ & $\begin{array}{l}\text { 48.08 } \pm 2 . \\
8 * *\end{array}$ \\
\hline 6 & $\begin{array}{l}\text { Fresh Plant biomass } \\
\text { per hill }(\mathrm{g})\end{array}$ & $\begin{array}{l}\mathbf{1 0 5 . 3 3} \pm 2 \\
* *\end{array}$ & $\begin{array}{l}185.3 \pm 2 . \\
6 * *\end{array}$ & $\begin{array}{l}\mathbf{1 0 0 . 6 7 \pm 1} \\
5^{*}\end{array}$ & $\begin{array}{l}\mathbf{1 0 9 . 3 \pm 4} \\
* *\end{array}$ & $\begin{array}{l}\text { 101 } \pm 3.6 * \\
*\end{array}$ & $\begin{array}{l}132 \pm 4.1 \\
* *\end{array}$ & $\begin{array}{l}140.67 \pm \\
4 * *\end{array}$ \\
\hline 7 & $\begin{array}{l}\text { Dry Plant biomass per } \\
\text { hill }(\mathrm{g})\end{array}$ & $\begin{array}{l}\mathbf{7 0 . 6 3} \pm 4.5 \\
* * \\
\end{array}$ & $\begin{array}{l}\text { 65.33 } \pm 5 . \\
1 * *\end{array}$ & $\begin{array}{l}\mathbf{4 8 . 3 3} \pm 2.5 \\
* *\end{array}$ & $\begin{array}{l}\text { 64.67 } \pm 0 . \\
58 *\end{array}$ & $\mathbf{5 2 \pm 4 . 0 * *}$ & $\begin{array}{l}\text { 63.67 } \pm 1 \\
5 * *\end{array}$ & $\begin{array}{l}\text { 64.33 } \pm 1 . \\
1 * *\end{array}$ \\
\hline 8 & $\begin{array}{l}\text { Fresh Root biomass } \\
\text { (g.) }\end{array}$ & $\begin{array}{l}\text { 16.67 } \pm 2.8 \\
* *\end{array}$ & $\begin{array}{l}\mathbf{5 1 . 3 3} \pm 3 \\
* *\end{array}$ & $\begin{array}{l}\text { 13.33 } \pm 1.1 \\
*\end{array}$ & $32 \pm 1.1^{*}$ & $\begin{array}{l}\mathbf{3 5 . 5 5} \pm 2.6 \\
* *\end{array}$ & $\begin{array}{l}\text { 22.67 } \pm 3 . \\
0 * *\end{array}$ & $\mathbf{1 8} \pm 2 * *$ \\
\hline 9 & Dry Root biomass (g.) & $10 \pm 0.12 *$ & $\begin{array}{l}12.33 \pm 0 . \\
5 *\end{array}$ & $6 \pm 0.2 *$ & $7.06 \pm 1 *$ & $\begin{array}{l}\mathbf{7 . 9 6} \pm 1.04 \\
*\end{array}$ & $\begin{array}{l}\text { 9.67 } \pm 2.8 \\
* *\end{array}$ & $9 \pm 2.6 * *$ \\
\hline 10 & Root Length (cm) & $\mathbf{1 5} \pm 1.0 *$ & $\begin{array}{l}\text { 13.17 } \pm 1 \\
3 *\end{array}$ & $\begin{array}{l}\mathbf{1 1 . 9 3} \pm 2.0 \\
* *\end{array}$ & $\begin{array}{l}\mathbf{1 4 . 5} \pm 0.1 \\
1 *\end{array}$ & $\begin{array}{l}\text { 17.330 } \pm 0 . \\
5 *\end{array}$ & $\begin{array}{l}\text { 14.67 } \pm 2 \\
* *\end{array}$ & $\begin{array}{l}14.67 \pm 3 . \\
2 * *\end{array}$ \\
\hline 11 & Days of Maturity & $135 \pm 1 *$ & $133 \pm 1 *$ & $130 \pm 1 *$ & $135 \pm 1 *$ & $133 \pm 1 *$ & $134 \pm 1 *$ & $130 \pm 1 *$ \\
\hline 12 & Panicle Length $(\mathrm{cm})$ & $\begin{array}{l}\text { 32.33 } \pm 2.5 \\
*\end{array}$ & $\begin{array}{l}\text { 29.33 } \pm 1 . \\
1 *\end{array}$ & $\begin{array}{l}\mathbf{2 6 . 6 7} \pm 1.2 \\
*\end{array}$ & $\begin{array}{l}35.00 \pm 1 \\
* *\end{array}$ & $\begin{array}{l}\text { 27.33 } \pm 2.5 \\
*\end{array}$ & $\begin{array}{l}\text { 31.67 } \pm 1 \\
5 *\end{array}$ & $\begin{array}{l}\text { 26.33 } \pm 1 . \\
5 *\end{array}$ \\
\hline 13 & $\begin{array}{l}\text { Grain yield per } \\
\text { plant }(\mathrm{g})\end{array}$ & $3 \pm 0.07 *$ & $\begin{array}{l}2.58 \pm 0.4 \\
*\end{array}$ & $\begin{array}{l}2.32 \pm 0.15 \\
*\end{array}$ & $3 \pm 0.03^{*}$ & $\begin{array}{l}\mathbf{2 . 7 5} \pm 0.19 \\
*\end{array}$ & $\begin{array}{l}\mathbf{2 . 9 5} \pm 0.0 \\
1 *\end{array}$ & $\begin{array}{l}\mathbf{3 . 5} \pm 0.45 \\
*\end{array}$ \\
\hline 14 & $\begin{array}{l}\text { Grain yield per hill } \\
\text { (g.) }\end{array}$ & 23 $\pm 1 *$ & $\begin{array}{l}36.67 \pm 1 \\
3 *\end{array}$ & $\begin{array}{l}\text { 21.33 } \pm 0.9 \\
*\end{array}$ & 29 $\pm 0 *$ & 38 $\pm 1 *$ & $\begin{array}{l}18.4 \pm 0.6 \\
*\end{array}$ & $\begin{array}{l}\mathbf{5 0 . 5 2 \pm 1 .} \\
2 *\end{array}$ \\
\hline 15 & Spikelets per panicle & $\begin{array}{l}200.33 \pm 1 . \\
5 * *\end{array}$ & $\begin{array}{l}\text { 123.67士 } \\
4 * *\end{array}$ & $\begin{array}{l}124.00 \pm 3 . \\
6 * *\end{array}$ & $\begin{array}{l}\mathbf{2 4 1} \pm 2.6 \\
* *\end{array}$ & $\begin{array}{l}\text { 108.33 } \pm 2 . \\
8 * *\end{array}$ & $116 \pm 1 * *$ & $\begin{array}{l}194.33 \pm \\
4 * *\end{array}$ \\
\hline 16 & 1000 Seed weight (g.) & $\begin{array}{l}\mathbf{2 3 . 5 2} \pm 1.5 \\
*\end{array}$ & $\begin{array}{l}\mathbf{2 1 . 6 3} \pm 1 \\
*\end{array}$ & $\begin{array}{l}\text { 18.19 } \pm 1.2 \\
*\end{array}$ & $\begin{array}{l}\text { 18.19 } \pm 0 . \\
9 *\end{array}$ & $\begin{array}{l}\text { 29.53 } \pm 0.5 \\
*\end{array}$ & $\begin{array}{l}27.38 \pm 1 \\
5 *\end{array}$ & $\begin{array}{l}\mathbf{2 6 . 6 8} \pm 1 \\
* *\end{array}$ \\
\hline
\end{tabular}

*Standard Error $(\mathrm{SE})<1$, **SE $<2$, SD- Standard deviation 
Table 4:- Morphological parameters of paddy varieties of Asaudha (Haryana) state.

\begin{tabular}{|c|c|c|c|c|c|c|c|c|}
\hline \multicolumn{9}{|c|}{ Asaudha (Haryana) state } \\
\hline \multirow{2}{*}{$\begin{array}{l}\text { S.N } \\
\text { o. }\end{array}$} & \multirow[t]{2}{*}{ Characters } & \multicolumn{7}{|c|}{$\begin{array}{r}\text { Paddy varieties } \\
\end{array}$} \\
\hline & & VB-21 & VB-22 & VB-23 & VB-24 & PB-1509 & PB-1121 & SS-1 \\
\hline 1 & Plant Height $(\mathrm{cm})$ & $115 \pm 1^{*}$ & $\begin{array}{l}\mathbf{9 2 . 3} \pm 2.5 \\
* *\end{array}$ & $\begin{array}{l}\mathbf{9 0 . 3} \pm 3.2 \\
* *\end{array}$ & $\begin{array}{l}\text { 106.67 } \pm 3 . \\
5 * *\end{array}$ & $\begin{array}{l}106.33 \pm 3 . \\
5 * *\end{array}$ & $106 \pm 3 * *$ & $\begin{array}{l}\mathbf{8 8 . 3} \pm 3.6^{*} \\
*\end{array}$ \\
\hline 2 & Tillers per Hill & $\begin{array}{l}\mathbf{1 3 . 3 3} \pm 0.6 \\
5^{*}\end{array}$ & $\begin{array}{l}16.33 \pm 0 . \\
5 * *\end{array}$ & $\begin{array}{l}11.33 \pm 2 . \\
5^{* *}\end{array}$ & $\begin{array}{l}\text { 11.33 } \pm 3.6 \\
* *\end{array}$ & $\begin{array}{l}\text { 13.67 } \pm 1.8 \\
* *\end{array}$ & $\begin{array}{l}\mathbf{1 8} \pm 2.3 * \\
*\end{array}$ & $\begin{array}{l}\mathbf{1 5 . 3 3} \pm 0.8 \\
5 * *\end{array}$ \\
\hline 3 & Flag leaf length $(\mathrm{cm})$ & $51 \pm 1 *$ & $\mathbf{5 0} \pm 0.5^{*}$ & $\begin{array}{l}\mathbf{4 8} \pm 1.6^{*} \\
*\end{array}$ & $\mathbf{5 9} \pm 1.1 * *$ & $67 \pm 1.9^{*}$ & $\begin{array}{l}\mathbf{5 8} \pm 1.4 * \\
*\end{array}$ & $\mathbf{5 1} \pm 1.3^{*}$ \\
\hline 4 & Flag leaf width $(\mathrm{mm})$ & $100 \pm 0.6^{*}$ & $\begin{array}{l}120 \pm 0.9 \\
*\end{array}$ & $180 \pm 1 * *$ & $\mathbf{1 0 0} \pm 1.2 *$ & $75 \pm 1.5 * *$ & $\mathbf{6 5} \pm 1.3^{*}$ & $70 \pm 1.1^{*}$ \\
\hline 5 & Leaf Area $\left(\mathrm{cm}^{2}\right)$ & $\begin{array}{l}\mathbf{3 5 . 5 2} \pm 2.6 \\
* *\end{array}$ & $37 \pm 1.5^{*}$ & $\begin{array}{l}\mathbf{4 7 . 7 8} \pm 2 . \\
9 *\end{array}$ & $\begin{array}{l}\mathbf{3 6 . 9 7} \pm 4.3 \\
*\end{array}$ & $\begin{array}{l}\mathbf{3 4 . 4 3} \pm 1.4 \\
*\end{array}$ & $\begin{array}{l}\text { 23.11 } \pm 2 . \\
6^{*}\end{array}$ & $\begin{array}{l}\mathbf{1 9 . 0 8} \pm 1.4 \\
* *\end{array}$ \\
\hline 6 & $\begin{array}{l}\text { Fresh Plants biomass } \\
\text { per gm. }\end{array}$ & $\begin{array}{l}162 \pm 3.6^{*} \\
*\end{array}$ & $140 \pm 3 * *$ & $\begin{array}{l}\mathbf{8 8 . 6 7} \pm 2 . \\
6^{* *}\end{array}$ & $94 \pm 2.5 * *$ & $\begin{array}{l}\text { 92.67 } \pm 2.8 \\
* *\end{array}$ & $\begin{array}{l}\mathbf{1 7 2} \pm 2.5 \\
* *\end{array}$ & $\begin{array}{l}\mathbf{1 7 3 . 3} \pm 2.5 \\
* *\end{array}$ \\
\hline 7 & $\begin{array}{l}\text { Dry Plants biomass } \\
\text { per (gm.) }\end{array}$ & $\begin{array}{l}\text { 72.67 } \pm 2 * \\
*\end{array}$ & $\begin{array}{l}\mathbf{5 0 . 5 8} \pm 1 \\
*\end{array}$ & $70 \pm 0.6^{*}$ & $\begin{array}{l}\mathbf{5 0 . 3 3} \pm 4 * \\
*\end{array}$ & $\begin{array}{l}\mathbf{5 1 . 6 7} \pm 0.6 \\
*\end{array}$ & 70 $\pm 0 *$ & $65 \pm 5^{* *}$ \\
\hline 8 & $\begin{array}{l}\text { Fresh Root biomass } \\
(\mathrm{gm} .)\end{array}$ & $52 \pm 2.5 * *$ & $\begin{array}{l}\mathbf{5 2 \pm 2 . 7 *} \\
*\end{array}$ & $14 \pm 1 *$ & $\begin{array}{l}\text { 40.67 } \pm 2.6 \\
* *\end{array}$ & $\begin{array}{l}\mathbf{3 8 . 6 7} \pm 3.2 \\
* *\end{array}$ & $\begin{array}{l}\text { 39.33 } \pm 4 . \\
3 * *\end{array}$ & $52 \pm 2.9 * *$ \\
\hline 9 & $\begin{array}{l}\text { Dry Root biomass } \\
(\mathrm{gm} .)\end{array}$ & $\begin{array}{l}\mathbf{1 2 . 5 7} \pm 1.3 \\
*\end{array}$ & $\begin{array}{l}13.59 \pm 0 . \\
6^{*}\end{array}$ & $\begin{array}{l}\mathbf{6 . 6 7} \pm 0.6 \\
*\end{array}$ & $\mathbf{8 . 3 3} \pm 1.5^{*}$ & $7.5 \pm 0.5^{*}$ & $\begin{array}{l}\mathbf{1 0 . 6 7} \pm 2 \\
* *\end{array}$ & $\begin{array}{l}\mathbf{1 0 . 6 7 \pm 1 . 7} \\
*\end{array}$ \\
\hline 10 & Root Length $(\mathrm{cm})$ & $\begin{array}{l}\mathbf{1 6 . 3 3} \pm 1.5 \\
*\end{array}$ & $\begin{array}{l}13.67 \pm 0 . \\
6^{*}\end{array}$ & $\begin{array}{l}13.67 \pm 0 . \\
6^{*}\end{array}$ & $\begin{array}{l}\text { 13.33 } \pm 0.3 \\
*\end{array}$ & $\begin{array}{l}\text { 16.67 } \pm 2.8 \\
*\end{array}$ & $\begin{array}{l}\mathbf{1 5 . 8 3} \pm 2 . \\
4 * *\end{array}$ & $\begin{array}{l}\mathbf{1 5 . 5} \pm 0.5^{*} \\
*\end{array}$ \\
\hline 11 & Days of Maturity & $130 \pm 1^{*}$ & $132 \pm 2 *$ & $130 \pm 1^{*}$ & $134 \pm 1^{*}$ & $129 \pm 1 *$ & $132 \pm 1^{*}$ & $125 \pm 1^{*}$ \\
\hline 12 & Panicle Length $(\mathrm{cm})$ & $\begin{array}{l}\text { 27.33 } \pm 1.5 \\
* *\end{array}$ & $\begin{array}{l}27.67 \pm 0 . \\
6^{*}\end{array}$ & $\begin{array}{l}26.33 \pm 1 . \\
5^{*}\end{array}$ & 32.67 $\pm 2 *$ & $\mathbf{2 8} \pm 0.00 *$ & $\begin{array}{l}29.54 \pm 0 . \\
5 *\end{array}$ & $\begin{array}{l}\mathbf{2 8 . 1 3} \pm 1.0 \\
4 * *\end{array}$ \\
\hline 13 & $\begin{array}{l}\text { Grain yield per plant } \\
(\mathrm{gm} .)\end{array}$ & 3.33 $\pm 0.2 *$ & $\begin{array}{l}\mathbf{2 . 4 6} \pm 0.6 \\
*\end{array}$ & $\begin{array}{l}\mathbf{2 . 6 4} \pm 0.1 \\
*\end{array}$ & $\begin{array}{l}\mathbf{2 . 6 7} \pm 0.01 \\
*\end{array}$ & $2.3 \pm 0.03 *$ & $\begin{array}{l}\mathbf{2 . 5 5} \pm 0.1 \\
8^{*}\end{array}$ & $2.5 \pm 0.09^{*}$ \\
\hline 14 & $\begin{array}{l}\text { Grain yield per HILL } \\
(\mathrm{gm} .)\end{array}$ & $\begin{array}{l}\mathbf{5 1 . 0 6} \pm 0.8 \\
*\end{array}$ & $\begin{array}{l}\mathbf{2 3 . 8 5} \pm 0 . \\
2 *\end{array}$ & $\begin{array}{l}18.59 \pm 0 . \\
5^{*}\end{array}$ & $\begin{array}{l}\mathbf{3 0 . 2 6} \pm 0.8 \\
5 *\end{array}$ & $\begin{array}{l}\mathbf{3 6 . 4 9} \pm 0.5 \\
7 *\end{array}$ & $\begin{array}{l}\mathbf{3 0 . 0 6} \pm 0 . \\
77 *\end{array}$ & $46 \pm 2.6 * *$ \\
\hline 15 & Spikelets per panicle & $\begin{array}{l}147.33 \pm 2 . \\
5 * *\end{array}$ & $\begin{array}{l}\text { 114 } \pm 3.6 \\
* *\end{array}$ & $\begin{array}{l}\mathbf{9 4} \pm 3.6^{*} \\
*\end{array}$ & $230 \pm 5 * *$ & $\begin{array}{l}\text { 111.67 } \pm 2 . \\
5 * *\end{array}$ & $\begin{array}{l}\mathbf{1 1 6} \pm 3.6 \\
* *\end{array}$ & $\begin{array}{l}\mathbf{1 5 8} \pm 3.6^{*} \\
*\end{array}$ \\
\hline 16 & $\begin{array}{l}1000 \text { Seed weight } \\
\text { (gm.) }\end{array}$ & $\begin{array}{l}\mathbf{2 9 . 0 0} \pm 0.6 \\
*\end{array}$ & $\begin{array}{l}26.47 \pm 1 . \\
2 *\end{array}$ & $\begin{array}{l}\mathbf{2 3 . 3 0} \pm 1 . \\
1 *\end{array}$ & $\begin{array}{l}\mathbf{2 6 . 6 1} \pm 0.8 \\
*\end{array}$ & $\begin{array}{l}\mathbf{2 6 . 1 8} \pm 0.0 \\
3 *\end{array}$ & $\begin{array}{l}16.97 \pm 0 . \\
45^{*}\end{array}$ & 23.25 $\pm 1 *$ \\
\hline
\end{tabular}

*Standard Error $(\mathrm{SE})<1, * * \mathrm{SE}<2, \mathrm{SD}-$ Standard deviation

Evaluation of the fragrance marker $f g r$ gene:-

The fragrance of Basmati rice varieties is a peculiar phenotypic trait which increases its demand and cultivation. The presence of $f g r$ gene in rice is a single recessive allele at a locus on chromosome 8 . The product of this gene is 2 acetyl-l-pyrroline (2AP) that gives Basmati rice its typical mild desirable aroma [3,9]. Rice genotypic study was carried out to evaluate the presence of $f g r$ gene in seven varieties of rice selected in this study. Using the markers specific to the $f g r$ gene PCR was carried out as per the protocol. The marker specific gene amplification of the $f g r$ gene was observed in all the rice varieties taken in the study. Exception was observed with Sambha Sub - 1 variety which showed minimal or null amplification with the Nested PCR primers ESP + IFAP + INSP + EAP and RM 515 respectively. Lower or Higher DNA bands from PCR of few of the varieties were also observed. This may be due to difference of few base pairs in the $f g r$ gene length under environmental adaptability. Thus, Fragrance genotyping helped us to confirm the presence of the fragrance gene in the varieties of rice considered in this study. 


\section{Biochemical Assays:-}

Figure 1:- Fragrance genotyping of the Rice varieties.

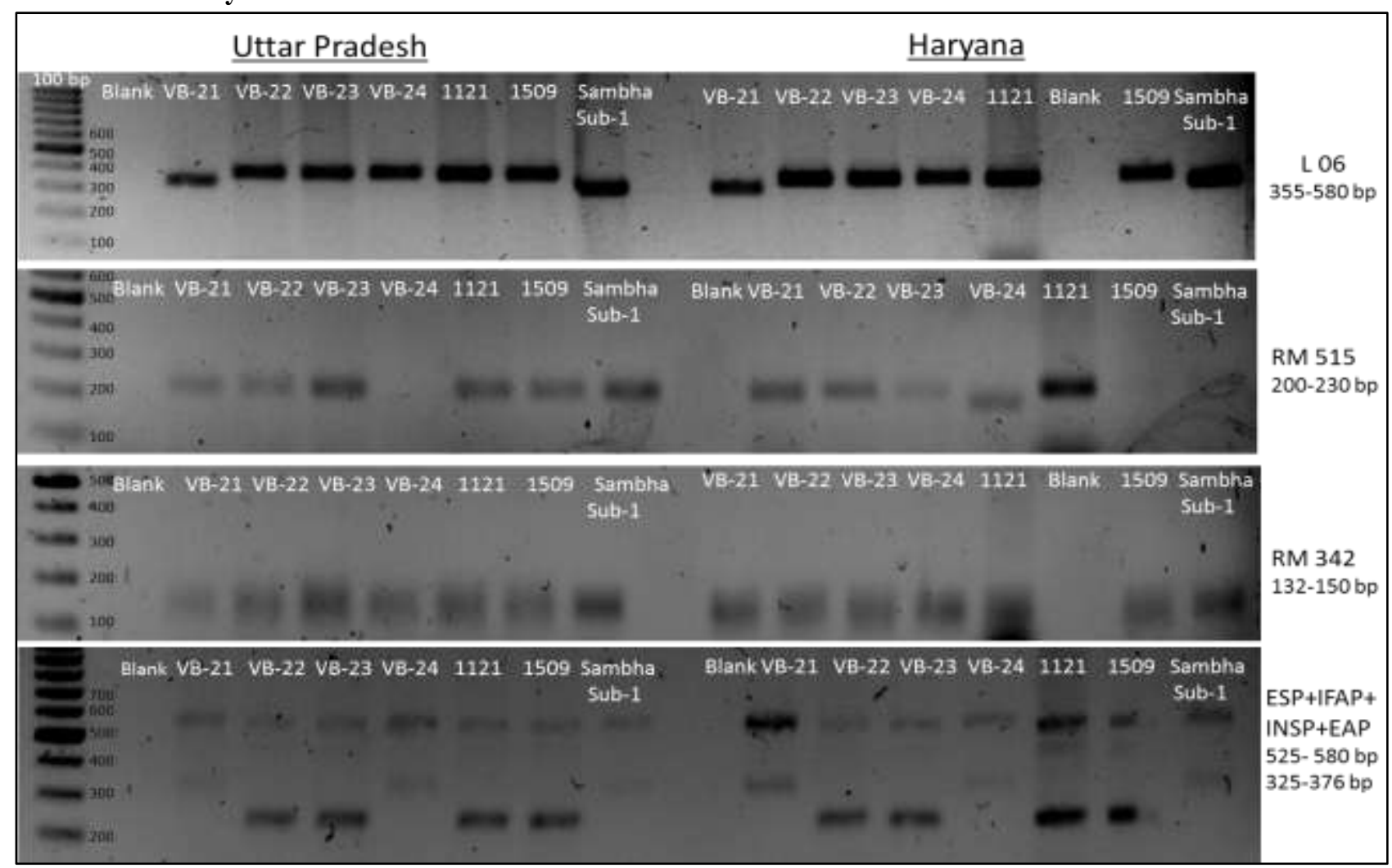

\section{Estimation of Chloroplast:-}

Amount of chlorophyll in the leaves determines the amount of sunlight that is absorbed by the plants which increases the rate of light reactions in the chloroplast and thus the rate of photosynthesis. As a result food produced in the grain in the form of starch increases which enhance the grain yield. Chloroplast from the leaf of each rice variety was isolated in the vegetative stage of the rice development and total chlorophyll was measured spectroscopically at $645,663 \& 652 \mathrm{~nm}$. The content of total chlorophyll, chlorophyll a and chlorophyll b for each rice variety is given in Table 5. Paddy varieties VB-23, PB-1121 and PB-1509 showed the presence of highest amount of total chlorophyll and chlorophyll a in the leaves in both the regions of Uttar Pradesh and Haryana. While other varieties like VB-21, VB-24 and SS-1 also had good amount of total chlorophyll and chlorophyll a in the leaves in both the regions.

\section{Assay of Rice Fragrance:-}

Apart from quality of rice seed such as grain size, seed luster and weight of the seeds; aroma of the rice, especially among the varieties of Basmati makes them a grain of choice in the market. To assess the fragrance in the seven varieties selected in the present study, the rice seeds were assayed for fragrance by $\mathrm{KOH}$ method. For the assessment 1-4 scoring scale with 1, 2, 3 and 4 corresponding to absence of aroma, slight aroma, moderate aroma and strong aroma, respectively was considered. The score for each sample was recorded by a panel of five experts who have experience in aromatic rice breeding and quality evaluation is listed in Table 6. VB-21, VB-24, PB-1509 had strong aroma while VB-23 and PB-1121 had moderate and VB-22 had slight aroma. These results along with the genotypic study had characterized VB-21, VB-22, VB-23, VB-24, PB-1509, and PB 1121 as Basmati varieties and Smbha-Sub-1 as a non-basmati variety. These findings are similar to the study done by Singh et al (2011) [4] that characterized the Basmati varieties VB-21, VB-22, VB-23, and PB-1509 from the non-Basmati varieties. 
Table 5:- Chlorophyll content in the leaves of each rice variety in two regions of India.

\begin{tabular}{|c|c|c|c|c|c|}
\hline Sr no. & Region & Rice variety & $\begin{array}{c}\text { Chlorophyll a } \\
\text { (mg/g) } \\
\text { SD } \pm 0.05 \\
\end{array}$ & $\begin{array}{c}\text { Chlorophyll b } \\
\text { (mg/g) } \\
\text { SD } \pm 0.055 \\
\end{array}$ & $\begin{array}{c}\text { Total chlorophyll } \\
\text { (mg/g) } \\
\text { SD } \pm 0.054 \\
\end{array}$ \\
\hline 1. & \multirow{7}{*}{$\begin{array}{l}\text { Hastinapur } \\
\text { Uttar Pradesh }\end{array}$} & Vallabh Basmati-21 & 1.3645 & 0.4337 & 2.6961 \\
\hline 2. & & Vallabh Basmati-22 & 0.9202 & 5.3023 & 4.6305 \\
\hline 3. & & Vallabh Basmati-23 & 4.6387 & 1.7291 & 9.3084 \\
\hline 4. & & Vallabh Basmati-24 & 1.3875 & 0.4964 & 2.7727 \\
\hline 5. & & Pusa Basmati-1121 & 1.4563 & 0.4799 & 2.8870 \\
\hline 6. & & Pusa Basmati-1509 & 3.4588 & 1.2229 & 6.9035 \\
\hline 7. & & Sambha Sub - 1 & 1.2376 & 0.3764 & 2.4358 \\
\hline 1. & \multirow{7}{*}{$\begin{array}{l}\text { Asaudha } \\
\text { Haryana }\end{array}$} & Vallabh Basmati-21 & 1.5946 & 0.5954 & 3.2004 \\
\hline 2. & & Vallabh Basmati-22 & 2.2379 & 0.8074 & 4.4758 \\
\hline 3. & & Vallabh Basmati-23 & 2.9036 & 1.0365 & 5.8009 \\
\hline 4. & & Vallabh Basmati-24 & 0.6024 & 3.6120 & 3.1104 \\
\hline 5. & & Pusa Basmati-1121 & 1.7834 & 0.5916 & 3.5376 \\
\hline 6. & & Pusa Basmati-1509 & 1.9036 & 0.6020 & 3.7596 \\
\hline 7. & & Sambha Sub - 1 & 2.3623 & 0.7835 & 4.6859 \\
\hline
\end{tabular}

\section{Estimation of total sugar and total protein:-}

Rice is the staple food of people among the Asian countries because it fulfills the requirement of carbohydrates. The amount of starch content in rice grain determines its quality and gives the estimate of calories it can produce. The protein content of the rice is however found to be low as the amount of starch stored in the seeds is higher. Thus, to evaluate the amount of starch protein content in the rice grain seeds of different varieties were collected after harvesting and were used for estimation of total sugar and total protein by Anthrone method and Bradford's method respectively. The results are listed in the Table 6 . As observed in the table, the total protein content in the rice seeds is low as compared to the total sugar content. However, it was also observed that the amount of total protein was higher in the rice varieties cultivated in the region of Haryana. This may be because of effect of high temperature and less humidity at the time of grain maturity and development. As evident the total sugar content in each rice variety in the region of Uttar Pradesh was found to be higher as the humidity and temperature required for plant maturity and grain development were optimally favorable.

\section{Statistical Studies:-}

\section{Association of morphological parameters:-}

Knowledge of the co-dependence of plant characters like grain yield with other morphological parameters paramount an important knowledge to the breeders for making improvement in the quantitative as well as qualitative characters in paddy. Hence, association of these characters was analyzed with respect to each rice variety as given in Table 7. The morpho-physiochemical characters of each rice variety in its area of cultivation and respective deviation from the mean value are listed in Table 3and 4.The correlation of the parameters with their respective correlation coefficient that are associated with each other is listed in Table 7. Plant height, Plant Biomass, Root Biomass, Leaf area, area, Length of the panicle, Spikelets per panicle, Days of Maturity and Grain yield per plant are found to be significantly correlated (P-value $>0.5)$ with each other.

Table 6:- Estimation of total protein, total sugar and aroma of the each rice variety.

\begin{tabular}{|c|c|c|c|c|c|}
\hline Sr no. & Region & Rice variety & $\begin{array}{c}\text { Total protein } \\
\text { (mg/g) } \\
\text { SD } \pm 0.04\end{array}$ & $\begin{array}{c}\text { Total Sugar } \\
\text { (mg/g) } \\
\text { SD } \pm 0.055\end{array}$ & $\begin{array}{c}\text { Aroma* } \\
\text { (1-4) Scale }\end{array}$ \\
\hline 1. & \multirow{7}{*}{$\begin{array}{l}\text { Hastinapur } \\
\text { Uttar Pradesh }\end{array}$} & Vallabh Basmati-21 & 73.106 & 264.4841 & 4 \\
\hline 2. & & Vallabh Basmati-22 & 92.602 & 232.464 & 2 \\
\hline 3. & & Vallabh Basmati-23 & 119.564 & 295.004 & 3 \\
\hline 4. & & Vallabh Basmati-24 & 116.927 & 292.046 & 4 \\
\hline 5. & & Pusa Basmati-1121 & 108.990 & 347.489 & 3 \\
\hline 6. & & Pusa Basmati-1509 & 126.568 & 267.497 & 4 \\
\hline 7. & & Sambha Sub - 1 & 113.208 & 280.783 & 1 \\
\hline
\end{tabular}




\begin{tabular}{|c|c|c|c|c|c|}
\hline 1. & \multirow{7}{*}{$\begin{array}{l}\text { Asaudha } \\
\text { Haryana }\end{array}$} & Vallabh Basmati-21 & 199.1876 & 265.24 & 4 \\
\hline 2. & & Vallabh Basmati-22 & 176.4433 & 201.048 & 2 \\
\hline 3. & & Vallabh Basmati-23 & 140.382 & 254.0392 & 3 \\
\hline 4. & & Vallabh Basmati-24 & 161.850 & 214.594 & 4 \\
\hline 5. & & Pusa Basmati-1121 & 132.636 & 212.2071 & 4 \\
\hline 6. & & Pusa Basmati-1509 & 143.196 & 358.2302 & 4 \\
\hline 7. & & Sambha Sub - 1 & 167.652 & 245.981 & 1 \\
\hline
\end{tabular}

*Aroma- 1-absence of aroma, 2- slight aroma, 3- moderate aroma, 4- strong aroma

The plant height was significantly correlated $(\mathrm{P}=0.560)$, panicle length $(0.868)$, Spikelets per panicle $(0.561)$, plant biomass (0.651) and days of maturity (0.746). Tillers per hill were found to be significantly correlated to root biomass (0.612), panicle length (0.54) and days of maturity (0.655). On the other hand, Plant biomass was significantly correlated to root biomass (0.66), leaf area (0.605), panicle length (0.611), spikelets per panicle (0.574), grain yield per plant (0.603) and days of maturity (0.566). Similar correlation between the morpho-physiochemical characters was found in a study conducted by Touhiduzzaman et al (2016) [19]. These parameters are significantly dependent upon each other such as if plants will be tall they will acquire proportionate amount of biomass in the shoot as well as the root. While, when leaf area is large plants can absorb more amount of sunlight that will help them to increase plant biomass and plant height. This requires more number of days to attain maturity and thus, this in turn will increase the yield of the grains per plant.

\section{Effect of Temperature and Humidity on the morphological characters:-}

Paddy is the plant of the Kharif season that requires humidity and optimum temperature as it attains maturity. Student's t test was done to find the co-dependence of the important morphological parameters upon temperature and humidity. The $\mathrm{P}$ value respective to each codependence of each parameters on temperature and humidity is listed in the Table 8. In this study, paddy was grown in two regions which have considerable difference in the temperature and humidity. The Maximum and minimum temperatures and humidity in the environment at the different stages of rice plant development are listed in Table 1. Uttar Pradesh has pleasant temperature and high humidity ideal for paddy cultivation. Haryana is comparatively dry with temperature higher to that in the region of Uttar Pradesh. In accordance to this, morphological parameters such as plant height, plant biomass, root biomass, root length were significantly correlated with the temperature and humidity that plants are subjected to. However, parameters such as leaf area, panicle length, spikelets per panicle, grain yield and weight and days taken by the plant to attain the maturity were found to be negatively correlated with the temperature and humidity. As the temperature rises and humidity is less the leaf area reduces so as to minimize the rate of water evaporation from the surface. Also, the chlorophyll content in the leaf decreases that affects the rate of photosynthesis. As described in the previous section reduced leaf area will affect the length of the panicle, spikelets per panicle and thus grain yield and weight that are found to be reduced in the region of Haryana with higher temperature and lower humidity compared to Uttar Pradesh region.

\section{Effects of temperature and humidity on biochemical parameters and their association of with the morphological parameters:-}

As found in the Table 9, the biochemical parameters such as total protein and total sugar content in the seeds was found to be positively correlated with chlorophyll content in the leaves, plant biomass, root biomass, spikelets per panicle, panicle length and grain yield per plant. However, with the increase in the temperature and decrease in humidity the total protein in the grains increases as the plants increase in size while the total sugar content decreases as amount of food stored in the grain is reduced. This result positively correlates the fact that as the grain yield per plant deceases, the total sugar in the seeds decreases that reduce the weight of the seeds. 
Table 7:- Estimation of correlation between the morpho-physiological characters of Rice.

\begin{tabular}{|c|c|c|c|c|c|c|c|c|c|c|c|}
\hline & $\begin{array}{l}\text { Plant } \\
\text { height }\end{array}$ & $\begin{array}{l}\text { Tillers } \\
\text { per hill }\end{array}$ & $\begin{array}{c}\text { Plant } \\
\text { Biomass }\end{array}$ & $\begin{array}{c}\text { Root } \\
\text { Biomass }\end{array}$ & $\begin{array}{c}\text { Root } \\
\text { Length }\end{array}$ & $\begin{array}{l}\text { Leaf } \\
\text { Area }\end{array}$ & $\begin{array}{c}\text { Panicle } \\
\text { length }\end{array}$ & $\begin{array}{c}\text { Spikelet } \\
\text { s per } \\
\text { panicle }\end{array}$ & $\begin{array}{c}\text { Grain } \\
\text { yield } \\
\text { per } \\
\text { plant } \\
(\mathrm{g})\end{array}$ & $\begin{array}{c}\text { Days of } \\
\text { Maturit } \\
y\end{array}$ & $\begin{array}{c}1000 \\
\text { Seed } \\
w t .\end{array}$ \\
\hline $\begin{array}{l}\text { Plant height } \\
(\mathrm{cm})\end{array}$ & 1.0000 & & & & & & & & & & \\
\hline $\begin{array}{l}\text { Tillers per } \\
\text { hill }\end{array}$ & 0.2112 & 1.0000 & & & & & & & & & \\
\hline $\begin{array}{l}\text { Plant } \\
\text { Biomass }(\mathrm{g})\end{array}$ & 0.6519 & 0.3763 & 1.0000 & & & & & & & & \\
\hline $\begin{array}{l}\text { Root } \\
\text { Biomass }(g)\end{array}$ & 0.0665 & 0.6128 & 0.6609 & 1.0000 & & & & & & & \\
\hline $\begin{array}{l}\text { Root Length } \\
(\mathrm{cm})\end{array}$ & 0.0266 & 0.0072 & 0.0903 & 0.0439 & 1.0000 & & & & & & \\
\hline $\begin{array}{l}\text { Leaf Area } \\
\left(\mathrm{cm}^{2}\right)\end{array}$ & 0.5604 & -0.3865 & 0.6051 & 0.1336 & 0.3367 & 1.0000 & & & & & \\
\hline $\begin{array}{l}\text { Panicle } \\
\text { length }(\mathrm{cm})\end{array}$ & 0.8682 & 0.5407 & 0.6115 & 0.0991 & 0.0814 & 0.2309 & 1.0000 & & & & \\
\hline $\begin{array}{l}\text { Spikelets per } \\
\text { panicle }\end{array}$ & 0.5611 & -0.1794 & 0.5747 & -0.1627 & 0.0242 & 0.5948 & 0.5578 & 1.0000 & & & \\
\hline $\begin{array}{l}\text { Grain yield } \\
\text { per plant }(\mathrm{g})\end{array}$ & 0.2621 & -0.2704 & 0.6036 & 0.1582 & 0.4401 & 0.6611 & 0.1519 & 0.5978 & 1.0000 & & \\
\hline $\begin{array}{l}\text { Days of } \\
\text { Maturity }\end{array}$ & 0.7468 & 0.6558 & 0.5668 & 0.2881 & 0.3939 & 0.2545 & 0.8883 & 0.3027 & 0.0762 & 1.0000 & \\
\hline $\begin{array}{l}1000 \text { Seed } \\
\text { weight }(\mathrm{g})\end{array}$ & -0.2194 & -0.0848 & 0.0296 & 0.2913 & 0.7652 & 0.2294 & -0.3232 & -0.3824 & 0.4328 & -0.0039 & 1.000 \\
\hline
\end{tabular}

- Correlation $\mathrm{P}>0.5$ is in bold.

Table 8:- Correlation study of morphological and biochemical parameters upon temperature and humidity

\begin{tabular}{|c|c|c|c|c|c|}
\hline \multirow[t]{2}{*}{ Morphological Parameters } & \multirow[t]{2}{*}{ P-value } & \multirow[t]{2}{*}{ t Stat } & \multirow[t]{2}{*}{ t Critical 2 tail } & \multicolumn{2}{|c|}{$\begin{array}{c}\text { Correlation } \\
\end{array}$} \\
\hline & & & & Temperature & Humidity \\
\hline Plant height & 0.26 & -1.18 & 2.20 & Positive & Negative \\
\hline Plant Biomass & 0.97 & -0.04 & 2.20 & Positive & Negative \\
\hline Root Biomass & 0.39 & -0.90 & 2.20 & Positive & Negative \\
\hline Root Length & 0.53 & -0.65 & 2.18 & Positive & Negative \\
\hline Leaf Area & 0.05 & 2.23 & 2.21 & Negative & Positive \\
\hline Panicle length & 0.40 & 0.87 & 2.23 & Negative & Positive \\
\hline Spikelets per panicle & 0.47 & 0.74 & 2.18 & Negative & Positive \\
\hline Grain yield per plant (g) & 0.23 & 1.25 & 2.18 & Negative & Positive \\
\hline Days of Maturity & 0.08 & 1.91 & 2.20 & Negative & Positive \\
\hline 1000 Seed weight & 0.68 & -0.42 & 2.18 & Negative & Positive \\
\hline Total Chlorophyll & 0.69 & 0.41 & 2.31 & Positive & Negative \\
\hline Chlorophyll a & 0.80 & 0.26 & 2.26 & Positive & Negative \\
\hline Chlorophyll b & 0.72 & 0.36 & 2.23 & Negative & Positive \\
\hline Total Protein & 0.85 & -0.19 & 2.20 & Positive & Negative \\
\hline Total Sugar & 0.63 & 0.49 & 2.26 & Negative & Positive \\
\hline
\end{tabular}

- When $\mathbf{t}$ Stat < $\mathbf{t}$ critical the null hypothesis is accepted and the correlation between the two variable is positive 
Table 9:- Correlation of biochemical parameters with the morphological parameters.

\begin{tabular}{|c|c|c|c|c|c|}
\hline & Total chlorophyll & Chlorophyll a & Chlorophyll b & Total protein & Total sugar \\
\hline Total chlorophyll & 1 & & & & \\
\hline Chlorophyll a & 0.93 & 1.00 & & & \\
\hline Chlorophyll b & 0.30 & -0.08 & 1.00 & & \\
\hline Total protein & 0.67 & 0.49 & 0.52 & 1.00 & \\
\hline Total sugar & 0.42 & 0.38 & 0.15 & -0.04 & 1.00 \\
\hline Plant height & -0.14 & -0.02 & -0.34 & -0.15 & 0.20 \\
\hline Tillers per hill & -0.05 & -0.30 & 0.64 & 0.10 & -0.07 \\
\hline Plant Biomass & -0.55 & -0.60 & 0.05 & -0.19 & $\mathbf{0 . 1 7}$ \\
\hline Root Biomass & -0.28 & -0.53 & 0.61 & 0.36 & -0.14 \\
\hline Root Length & -0.68 & -0.50 & -0.52 & -0.42 & -0.78 \\
\hline Leaf Area & -0.57 & -0.37 & 0.24 & -0.19 & -0.16 \\
\hline Panicle length & -0.25 & -0.21 & $\mathbf{0 . 8 3}$ & -0.38 & 0.17 \\
\hline Spikelets per panicle & -0.58 & -0.43 & 0.84 & -0.73 & 0.33 \\
\hline Grain yield per plant (g) & -0.68 & -0.51 & 0.02 & -0.56 & $\mathbf{0 . 1 0}$ \\
\hline Days of Maturity & -0.38 & -0.37 & 0.55 & -0.24 & -0.27 \\
\hline 1000 Seed weight & -0.33 & -0.23 & $\mathbf{0 . 2 3}$ & 0.07 & -0.60 \\
\hline
\end{tabular}

Bold $\mathrm{p}$ values $(\mathrm{P}>0.05)$ in the table shows positive correlation.

\section{Conclusion:-}

The statistical studies clearly explain a significant correlation $(\mathrm{P}>0.05)$ between the morpho-physiochemical characters of rice. Student's t test showed that the climatic temperature and the humidity have direct effects on the rice plant growth, gain yield and quality. The six out of seven rice varieties namely; VB-21, Vb-22, VB-23, VB-24, PB-1509, PB- 1121 have aroma of Basmati and presence of $f g r$ gene in the genome while Sambha Sub-1 is a nonbasmati variety. VB-21, VB-24, PB-1509, PB-1121 are among the rice varieties that show higher grain yield per plant and grain quality in both the regions of Northern India despite of climatic variations observed. While VB-21 and VB-24 shown higher grain yield as these can withstand higher temperature and lower humidity. These varieties can thus be used by the farmers in differential climatic regions of Northern India for Basmati production.

\section{Acknowledgement:-}

The authors are thankful to National Seeds Corporation, New Delhi, Indian Agriculture Research Institute, New Delhi and Basmati Import and Export Foundation, Meerut and the scientists for providing the different varieties of seeds for the present study. Also, special gratitude is extended to Dr. B. R Ambedkar Centre for Biomedical Research, University of Delhi, India for providing its research facilities.

\section{References:-}

1. Bhatt R.M, Srinivasa Rao, N.K. Veere Gowda (2004): Genotypic variability of physiological responses to water stress in onion (Allium cepa L.). Tropical Agriculture 81: 248-252.

2. Chen S, et al. (2008): Badh2, encoding betaine aldehyde dehydrogenase, inhibits the biosynthesis of 2-acetyl-1pyrroline, a major component in rice fragrance. Plant Cell 20:1850-1861.

3. Chen, S., Wu, J., Yang, Y., Shi, W. and Xu, M. (2006). The fgr gene responsible for rice fragrance was restricted within $69 \mathrm{~kb}$. Plant Science 171, 505-514.

4. Devi Singh, Anuj Kumar, Navneet. Kumar, Vipin Kumar, Sachin Kumar, Amal Bhardwaj, Preeti Sirohi and S. Chand (2011) Comparison of traditional physico-chemical methods and molecular marker assays for characterization of Basmati rice (Oryza sativa L.). African Journal of Biotechnology, Vol. 10(62), pp. 1339013398.

5. Hedge, J.E. and Hofreiter, B.T (1962). In: Methods in Carbohydrate Chemistry. Vol.17, (Eds.,) Whistler, R.L. and BeMiller, J.N., Academic Press, New York, p. 420.

6. Jewel Z. A. , Patwary A. K. , S. Maniruzzaman. S , Barua. R* and Begum. S. N (2011): Physico-chemical and Genetic Analysis of Aromatic Rice (Oryza sativa L.) Germplasm. The Agriculturists 9(1\&2): 82-88.

7. Keb-Llanes M, Gonzalez G, Chi-Manzanero B, Infante D (2002): A rapid and simple method for small scale DNA extraction in Agavaceae and other tropical plants. Plant Molecular Biology Reporter 20: 299a-299e. 
8. Kibria. K, Islam. MM, Begum S.N (2008): Screening of aromatic rice lines by phenotypic and molecular markers. Bangladesh Journal of Botany. 37(2): 141-147.

9. Lorieux, M., Petrov, M., Huang, N., Guiderdoni, E. and Ghesquiere, A. (1996) Aroma in rice: genetic analysis of a quantitative trait. Theoretical and Applied Genetics, 93, 1145-1151.

10. Louis M. T. Bradbury, Robert J. Henry, Qingsheng Jin, Russell F. Reinke, and Daniel L. E. Waters (2005): A Perfect Marker for Fragrance Genotyping in Rice. Molecular Breeding 16: 279-283.

11. Louis M. T. Bradbury, Robert J. Henry, Qingsheng Jin, Russell F. Reinke and Daniel L. E. Waters (2005): A perfect marker for fragrance genotyping in rice. Molecular Breeding 16: 279-283.

12. Michael J. Kovacha, Mariafe N. Calingacionb, Melissa A. Fitzgeraldb, and Susan R. McCouch (2009): Michael J. Kovacha, Mariafe N. Calingacionb, Melissa A. Fitzgeraldb, and Susan R. McCouch. PNAS .vol. 106 ,no. 34.

13. Nagaraju, Vasanthakumar, H.C., Devaiah, B. M., Seshadri, V.S. and Naidu, B.S., 1991, Evaluation of rice genotypes for blast and sheath rot resistance in hilly regions of Karnataka. Mysore. Journal of Aricultural Sciencei., 25: 139-141.

14. Nicholas J. Kruger (2002): The Bradford Method for Protein Quantitation. The Protein Protocols Handbook, 2nd Edition. 4: 15-21.

15. Paroda R.S, Kumar P (2000): Food production and demand in South Asia. Agricultural Economic Resources. Revision. 13: 1-24.

16. RAI V.P, Singh A.K, Jaiswal H.K, Singh S.P, Singh R.P, Waza S.A (2015): Evaluation of molecular markers linked to fragrance and genetic diversity in Indian aromatic rice. Turkish Journal of Botany. 39: 209-217.

17. Redona E. D, and D. J. Mackill, (1998): Quantitative trait locus analysis for rice panicle and grain characteristics. Theoretical and Applied Genetics. 96: 957-963.

18. Sadasivam S, Manickam A (1996) Biochemical methods. 2nd edition, New Age International (p) Ltd. Publisher, New Delhi, pp 179-186.

19. Sanjeev Ranjan, Rajesh Matcha, Madhuri B, Narendra Babu P V R (2012): Comparative elaluation of protein extraction methods from few leguminous seeds. International Journal of Advanced Biotechnology and Research. Vol 3, Issue 2, pp 558-563.

20. Touhiduzzaman1, Sikder RK2, Asif MI3, Mehraj H4* and Jamal Uddin AFM (2016): Correlation and Geneti Distance on Sixteen Rice Varieties Grown Under SRI. Advances in Plants \& Agriculture Research. 3(3): 00100.

21. Yoshida S (1981): Fundamentals of Rice Crop Science. International Rice Research Institute, Manila, Philippines 